\title{
REPORT FOR THE YEAR 1901.
}

By R. Etheridge, Junr., Curator.

["There should be no halt in the work of the Institution. ${ }^{1} \ldots$. The urgent needs of the National Museum are recommended to the favourable consideration of the Congress."'-Roosevelt, Presidential Messages to the U.S. Senate and House of Representatives.]

THE following Report treats of the work performed in the Australian Museum during 1901, and of the condition of the Collections therein.

It was decided last year to publish an account of the year's transactions as a Museum document pure and simple, rather than as a portion of the Statutory Report made by the Trustees under the Act of Incorporation (27 Vic., No. 2, 1853), to the State Governor. By issuing such a statement as a number of the Museum Records, it was felt that wider publicity would be given to the work of the year.

\section{General Condition and Care of Collections.}

The general condition of the Museum, as an Institution, remains in a very satisfactory state in all but its finances. It is useless to disguise the fact that the latter, as lately derived from the State funds, are not sufficiently liberal to conduct its affairs in a scientific and practical manner if it is to progress, maintain the high position attained amongst Colonial Museums, and not to stagnate. By rigid economy, and very careful management, income and expenditure have been balanced, but often at the expense of lost opportunities.

The whole of the Collections, both exhibited and in store, have been carefully watched, and are in excellent preservation.

The new Fish Gallery was opened to the public on 21 st August, and has since been largely frequented by visitors.

\section{Attendance of Public.}

The Museum continued open to visitors during the usual hours, viz., from 2 to 5 p.m. on Sundays, and from 10 a.m. to $5 \mathrm{p} \mathrm{m}$. on all week-days except Mondays, which were reserved for cleaning purposes; but on Monday afternoons the collections were, as usual,

1 The Smithsonian Institution at Washington. 
accessible to students and schools for teaching purposes, on application being made to me. The total number of visitors recorded was 166,676 , showing an increase of 48,749 for the year. The average was 469 (325 the previous year) on week-days, and 834 (601 the previous year) on Sundays. The largest attendance on any one day occurred during the Commonwealth celebrations, on the 2nd January, when 2,142 persons entered the building; and on the 28th May, during the visit of the T.R.H. the Duke and Duchess of Cornwall and York, 2,043 persons entered; but this is not equal to the number on Eight Hours' Day, 1st October, 1900, when 2,291 persons entered. The large increase mentioned was no doubt due to the influx of visitors during both of these holiday times.

\section{Commonwealth Festivities.}

On the occasion of the festivities at the beginning of the year, in connection with the inauguration of the Commonwealth of Australia, the Museum was entirely closed to the public on one day, during which the official procession passed the building. The Trustees offered the use of the ground attached to the private entrance to the Government for the erection of a grandstand. This offer was accepted, and the space was let by the Government to a contractor, the rent being afterwards repaid to the Trustees. The latter were accommodated with seats by the lessee, and the Museum officials and their friends were similarly provided on the large expanse of Museum roof. The arrangements made appeared to give general satisfaction, notwithstanding that upwards of nine hundred visitors were provided for, due in a great measure to the close attention paid to their duties by the Museum Special Constables, who were in charge of the proceedings. By the courtesy of the Government, a military band was placed within the enclosure and contributed to the general enjoyment. The building was illuminated at night during the entire festival week, when a portion of the Museum Fire Brigade was constantly on duty, under the control of a member of the Metropolitan Fire Brigade.

The Museum was again closed for a portion of the day on which T.R.H. The Duke and Duchess of Cornwall and York were welcomed to Sydney, the procession again passing the premises. An improvised stand for the Museum Staff and their friends was erected by our own mechanics.

\section{Museum Staff.}

Dr. Thomas Cooksey's term of service as Consulting Mineralogist having expired, it was determined to fill the vacancy by a direct appointment. The Trustees selected Mr. Charles Anderson, M.A., B.Sc. (Edin.), of Ben Nevis Observatory, from a large number of applicants, to take up the duties of Mineralogist and Chemist IIr. Anderson commenced his duties on 22nd July. 
The Trustees having decided to fill a long-felt want by the appointment of a special Mechanical Assistant to the Curator, to relieve me of a large amount of necessary but tedious work, Mr. W. W. Thorpe, an Attendant in the Museum, was in February selected from amongst very many applicants, and it affords me much pleasure to report that the 'Trustees' choice has been fully justified by the cordial assistance I have received from him. To fill the vacancy thus caused amongst the Attendants, J. C. Cullen was promoted from the position of Labourer. This caused a further vacancy, and to fill it T. Corrigall, who possessed strong recommendations, was selected. It was, however, with feelings of unfeigned regret that it became my duty to report to the Trustees the death of Mr. Corrigall, on 8th July, from meningitis supervening on typhoid fever. Although occupying but a humble position in our service, Mr. Corrigall was worthy of far higher employment, and had he been spared I have not the slightest doubt he would have risen rapidly in the Trustees' service, for which he was qualifying himself by hard study, in fact his illness was intensified through this cause. The vacancy thus caused was immediately filled by the appointment of S. H. Minnis.

The necessary funds having been voted by Parliament for the employment of a second Mechanical Assistant, Mr. Allan R. McCulloch, who for the past two years had been voluntarily assisting Mr. E. R. Waite, was selected for appointment as soon as the funds should be available by the passing of the Appropriation Act.

Another volunteer Assistant (Mr. H. L. Kesteven) afforded very valuable and disinterested help throughout the year in the Conchological Section.

\section{Structural Details.}

The two half-galleries of the new South Wing, as anticipated in my 1900 report, were completed by Mr. J. Howie, Contractor, within the specified time, and were handed over to the Department of Public Works in March, and by the latter to the Trustees on the 17th April. These half-galleries are each eighty-eight feet long by forty-five feet wide, with an approximate height of twentyfive feet. The lower is lit by windows from the side, placed at such a height as to permit a clear run of wall cases to be erected beneath them without recourse to the pernicious system of bays. The upper gallery is lit from above on the lantern principle. The north and south walls are of "Sydney Sandstone," the east and west being merely temporary ends of brick. The first floor consists of eighteen inches of coke concrete on the back of traegerioellbleck iron, followed by encaustic tiles set in cement. The second floor is formed by filling in with terra-cotta lumber, eight inches thick, 
between rolled steel joists, the whole surmounted again by encaustic tiles set in cement. The staircase leading from one hall to the other is easily graded, and consists of a steel framework, filled in with coke concrete, rendered in Kean's cement, with slate treads on top, a cast-iron ornamental railing carrying a polished cedar hand-rail. There are four pillars along each side of the two halls, those of the lower with slightly ornate capitals. The ceiling is divided into large white panels, bordered around the steel joists with stamped steel mouldings (Wunderlich), delicately picked out and tinted in low-toned colours. In the upper hall the pillars, instead of possessing capitals, carry cast-iron scroll brackets, which assist in supporting the glass lantern. The lantern proper is composed of metal framing and plate-glass with louvres, the supplementary inner and horizontal portion of ground glass. The ceiling on each side of the lantern is horizontal in oblong panels surrounded by arched sides to the walls, the former broken up into small square panels; the whole composed of Wunderlich stamped steel, suitably tinted. The roof is built of oregon, covered with copper sheeting.

\section{Fire Appliances.}

The Metropolitan Fire Brigade still continues its supervision of the fire extinguishing appliances, as of old, and it is almost superfluous to say the latter are in good order, and ready for instant use.

Under the superintendence and instruction of a member of the Brigade (Fireman F. Brooks, of the Head Station), regular periodical drills of the whole Staff were held. Instruction is confined to the rapid and effectual use of what may be termed "first-aid" appliances, such as the building is supplied with, including ladder work. Each member is first taught separately, and then so many in a squad are instructed how to work together. Our Officers are all assigned stations throughout the Museum, so many to each hydrant, etc. ; thus, on an alarm of fire, no loss of time would occur or confusion arise. A printed list of the stations, and the names of those assigned to each, is suspended in every office and workroom throughout the building.

\section{New Cases.}

Contract work of this nature, carried out during 1901, or to be put in hand through funds voted for that year, was as follows:-

The first instalment of the new Conchological cases was placed in position, as foreshadowed in my Report for 1900. It was decided after the passing of the 1901-2 Estimates, to provide an additional six cases of this nature, to be ready during the current year. Another wall case for the Geological Hall, and two additional cases for Fish, to be placed on stair landings near the entrance to the Fish Gallery were sanctioned. The casing of a 
portion of the two new half-galleries of the South Wing, was also taken into consideration, and it was decided to expend the special vote provided for this purpose, as far as it would go, by erecting wall cases in the upper of the two, for the reception of the Ethnological Collection, as suggested by me in various reports made to the Trustees.

The new case in the Geological Hall is destined to contain specimens of a strictly Geological rather than Palæontological nature.

The reference cards of the Zurich Catalogue of Scientific Papers having outgrown the receptacle allotted to them, an additional cabinet was ordered.

\section{Collecting and Field Work.}

In the words of last year's Report, "the collection of specimens remains almost dependent on the voluntary efforts of members of the Staff and friends who are willing to devote some portion of their time to it." By this means 489 specimens were added, as against 1,742 in 1900 , showing a decrease of 253 specimens.

Mr. W. S. Thompson, of Lord Howe Island, continued his efforts to supply our wants from that rich collecting ground, by forwarding Insects, Fishes. and Crustacea.

Messrs. F. Danvers Power and A. E. Stephen, who visited Ocean and Pleasant Islands on behalf of the Pacific Islsnds Company, were permitted by the Directors to give considerable attention to collecting for the Museum. Through their efforts, 428 Crustacea, 10 Echinoderms, 64 Fishes, 5 Birds, 6 Reptiles, and 24 Insects and Arachnids were secured.

Dr. E. P. Ramsay devoted much time to the collection of Insects, on the Trustees' behalf, in the ncighbourhood of Sydney, and was very successful.

Mr. A. J. North continued his avifaunian researches in the home district as time would permit, and at Ourimbah, and secured not only numerous specimens buc also valuable lifehistory data.

Both Mr. T. Whitelegge and Mr. W. J. Rainbow rendered valuable help in their respective sections. The former took advantage of some heavy gales and storms that visited this part of the Australian coast in July, to visit the ocean beaches, and was fortunate in securing several Sponges new to our Collection.

The Taxidermist (Mr. J. A. Thorpe) visited Tarana during his vacation, and applied his well-known collecting abilities in replenishing our duplicate Bird series, as well as obtaining some valuable nests and eggs. The Assistant Taxidermist (Mr. R. Grant) also collected in the immediate neighbourhood of Sydney. 
Mr. B. Lucas visited the Bellinger River, and obtained Birds and fœtal Marsupials.

The following is a statement of the specimens collected:-

\begin{tabular}{|c|c|c|c|c|c|c|}
\hline Mammali & & $\cdots$ & $\cdots$ & $\cdots$ & $\cdots$ & 2 \\
\hline Aves & $\ldots$ & $\ldots$ & $\ldots$ & $\cdots$ & $\ldots$ & 131 \\
\hline Reptilia & $\ldots$ & $\ldots$ & $\ldots$ & $\ldots$ & $\ldots$ & 6 \\
\hline Pisces & $\ldots$ & $\ldots$ & $\ldots$ & $\ldots$ & $\ldots$ & 85 \\
\hline Mollusca & $\ldots$ & $\ldots$ & $\ldots$ & $\ldots$ & $\ldots$ & \\
\hline Insecta, e & etc. & $\ldots$ & $\ldots$ & $\ldots$ & $\ldots$ & 90 \\
\hline Other In & vertebrat & ata & $\cdots$ & $\ldots$ & $\cdots$ & 7 \\
\hline & otal & $\cdots$ & $\ldots$ & $\cdots$ & $\ldots$ & 48 \\
\hline
\end{tabular}

\section{Presentations.}

The specimens presented during 1901 were very numerous and valuable, 14,954, as against 7,089 in 1900 , or an increase of 7,865 specimens.

The more important donations were:-

1. Marine and land animals from New Britain-by Dr.J.F. Flashman.

2. Skull of a fine Babirusa (B. babirusa) from Celebes-by $M r$. E. V. Bensusan.

3. A Native Companion (Grus australasianus, Gould), with ossified tendons-by The Council, Zoological Society of New South Wales.

4. The Pelagic fish known as the Luvaru (Luvarus imperialis, Raf.)-by Fishery Commissioners of $N$. S. Wales.

5. Numerous Marsupials - by Messrs. F. C. Jansen and J. Stringer.

6. One hundred and forty-five Australian, American, and European Fishes - by Mr. J. D. Ogilby.

7. A fine Sawfish (Pristis zysron, Bleek.) - by Mr. J. E. Chinnery.

8. A remarkably fine collection of marine organisms from the Barrier Reef waters, including Fish, Sponges, Actinozoa, Echinodermata, and Crustacea, in all 273 specimens, accompanied by 6,462 Mollusca-by $\mathrm{Mr}$. C. Hedley.

9. A Basking Shark (Cetorhinus maximus, Gunner.), and a number of other fish from Twofold Bay-by Mr.J.A. Boyd.

10. Five hundred and seventy-eight Sponges from our own coast - by Fishery Commissioners of N.S. Wales. 
11. Four hundred and seventy-eight Sponges (portions of types) -by Prof. A. Dendy, D.Sc.

12. Five hundred and thirteen Spiders from Jenolan-by $M r$. J. C. Wiburd.

13. One hundred and eighty Spiders from the Pacific Islandsby $M r . J . J$. Walker, R.N.

14. One hundred and seventy-one Beetles from the Weddin Mountains-by $M r . H$. W. Cox.

15. One hundred and six Beetles from around Sydney and the Blue Mountains-by Mr. H. J. Carter, M.A.

16. One hundred and ten New Hebridean Butterflies-by Rev. Dr. Annand.

17. Valuable collection of Mosquitos, from N.W. India-by Major G. M. Giles, I.M.s.

18. One thousand and sixty-eight Mollusca, from Geraldton, W.A. - by Mr. A. U. and the Rev. P. U. Henn.

19. Seventeen hundred and ninety-eight Mollusca, from Australian and South Pacific localities-by Mr. C. Hedley.

20. Ceremonial and Signal "Drum," from Mallicollo-by Rev. F'. Paton.

21. Shell Money in process of manufacture, from New Britainby $M r s . E$. E. Kolbe.

22. Skull trophy and carrying bag, from British New Guineaby $M r . P$. G. Black.

23. Four large Nardoo stones - by Mr. J. S. Jackson.

24. Ethnological objects from Ocean and Pleasant Islands-by Directors, Pacific Islands Co.

25. Kopi Widow's Cap-by Mr. G. Officer.

26. Bronze Medal, commemorating the equipment and departure of the "City Imperial Volunteers" to the Boer War-by Corporation, City of London.

27. Bronze Medal, "To the Memory of those who gave their lives for Queen and Country" (Boer War)-by Mr. Emil Fuchs.

28. Bronze Medal, "In Memory of Queen Victoria"-by Mr. Emil Fuchs.

29. Gold, Silver, and Bronze Medals, struck by the State Government of N. S. Wales in 1900-by State Premier (Hon. J. See, M.L.A.)

30. Gilt Medal, struck by the State Government of Victoria to commemorate the opening of the Commonwealth Parliament in 1900-by State Premier, Victoria. 
31. Gilt Medal, struck by the State Government of Queensland to commemorate the establishment of Australian Federation-by State Premier, Queensland.

32. Four Medals of the Royal Geographical Society of Londonby The Council.

33. Six Medals of the Society of Arts, London-by The Council.

34. Eight Medals of the Pharmaceutical Society of Great Britain -by The Council.

35. Eight Medals of the Institute of Civil Engineers, Londonby The Council.

36. Carved Cheval Glass, two Umbrellas, and a Standard, from Pekin-by State Premier (Hon. J. See, M.L.A.)

37. Eight Boer Rifles-by Major-Gen. Pretyman.

The following is a full statement of the specimens received:-

\begin{tabular}{|c|c|c|c|c|}
\hline Mammalia & $\cdots$ & $\ldots$ & $\cdots$ & 41 \\
\hline Aves & $\ldots$ & $\cdots$ & $\ldots$ & 449 \\
\hline Reptilia ... & $\ldots$ & $\ldots$ & $\ldots$ & $\ldots$ \\
\hline Pisces & $\cdots$ & $\cdots$ & $\ldots$ & 299 \\
\hline \multicolumn{3}{|c|}{ Skeletons (specimens for) } & $\ldots$ & 32 \\
\hline Mollusca ... & $\ldots$ & ... & $\ldots$ & $\ldots 9,966$ \\
\hline Insecta, etc. & $\ldots$ & . & $\ldots$ & $\ldots 1,745$ \\
\hline Other Invertebı & ata & $\cdots$ & $\ldots$ & $\ldots 1,362$ \\
\hline Fossils & $\ldots$ & ... & $\ldots$ & 296 \\
\hline Minerals ... & $\ldots$ & $\cdots$ & $\ldots$ & 219 \\
\hline Ethnological sp & cimens & . & $\cdots$ & 346 \\
\hline Historical speci & mens & $\cdots$ & $\cdots$ & $\cdots$ \\
\hline Numismatical s & pecimen & & $\ldots$ & $\ldots$ \\
\hline Miscellaneous & $\cdots$ & $\cdots$ & $\ldots$ & $\cdots$ \\
\hline Total & $\ldots$ & $\ldots$ & $\cdots$ & 14,954 \\
\hline
\end{tabular}

\section{Exchanges.}

In 1900, only 580 specimens were acquired by exchange. Last year 686 were so received, showing an increase of 106 . The principal acquisitions were:-

1. Birds-from South Australian Museum, Adelaide.

2. Reproduction of the Boogaldie Meteorite-from Technological Museum, Sydney.

3. Reproduction of the Rhine Valley Meteorite-from School of Mines and Industries of South Australia, Adelaide.

4. American Insects-from Mr. E. K. Harvey.

5. Bowls, Poi-board, etc.-from Bernice Pauahi Bishop Museum, Honolulu. 
6. Coins (various)-from $M r$. Coleman P. Hynam.

7. Rare Australian Insects-from Mr. C. French.

8. Shoulder Girdles of Birds-from $M r . E$. R. Waite.

9. American Spiders-from Dr. G. W. Peckham.

10. Phallic Grave-stone-from Mr. P. Williams.

The following is a statement of the specimens received:-

\begin{tabular}{|c|c|c|c|c|}
\hline Mammals... & $\cdots$ & $\cdots$ & $\cdots$ & 8 \\
\hline Aves & $\ldots$ & $\ldots$ & $\ldots$ & 21 \\
\hline Pisces & & & $\ldots$ & 42 \\
\hline Mollusca ... & $\ldots$ & $\ldots$ & $\ldots$ & 61 \\
\hline Insecta, etc. & $\ldots$ & & $\ldots$ & 381 \\
\hline Other Invertebrata & $\ldots$ & $\ldots$ & $\cdots$ & 34 \\
\hline Fossils $\quad \ldots \quad \ldots$ & $\ldots$ & $\ldots$ & $\ldots$ & 104 \\
\hline Minerals ... & $\ldots$ & $\ldots$ & $\ldots$ & 4 \\
\hline Ethnological specimens & & & $\ldots$ & 8 \\
\hline Numismatical specimen & & $\ldots$ & $\ldots$ & 17 \\
\hline Miscellaneous $\quad \ldots$ & $\ldots$ & $\cdots$. & 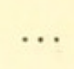 & $G$ \\
\hline Total & $\ldots$ & $\ldots$ & .. & 686 \\
\hline
\end{tabular}

\section{Purchases.}

Our purchasing power was again much less during last year, 690 specimens having been acquired in 1901, as against 1,645 in 1900 , showing a decrease of 955 specimens.

The more important specimens obtained by this means were:-

1. Human Crania, from New Caledonia, one of great dental interest.

2. Fine Club, believed to be from the New Britain Archipelago.

3. Coil of Santa Cruz feather "money."

4. Rare North Queensland Lepidoptera.

5. Commercial Sponges for comparative purposes.

6. Crystals of Chiastolite from South Australia.

7. Fine Bison's head.

8. Five-year old Lion.

9. Fine Turtle-shell Mask, from Torres Strait.

10. Large number of Ethnological specimens from Australia and the Pacific Islands, many of them rare and interesting.

11. Series of Medaletes struck in Australia to commemorate the consummation of Australian Federation.

12. Series of Medaletes struck in Australia to commemorate the death of H.M.G.M. Queen Victoria. 
The following is a full return of purchases :-

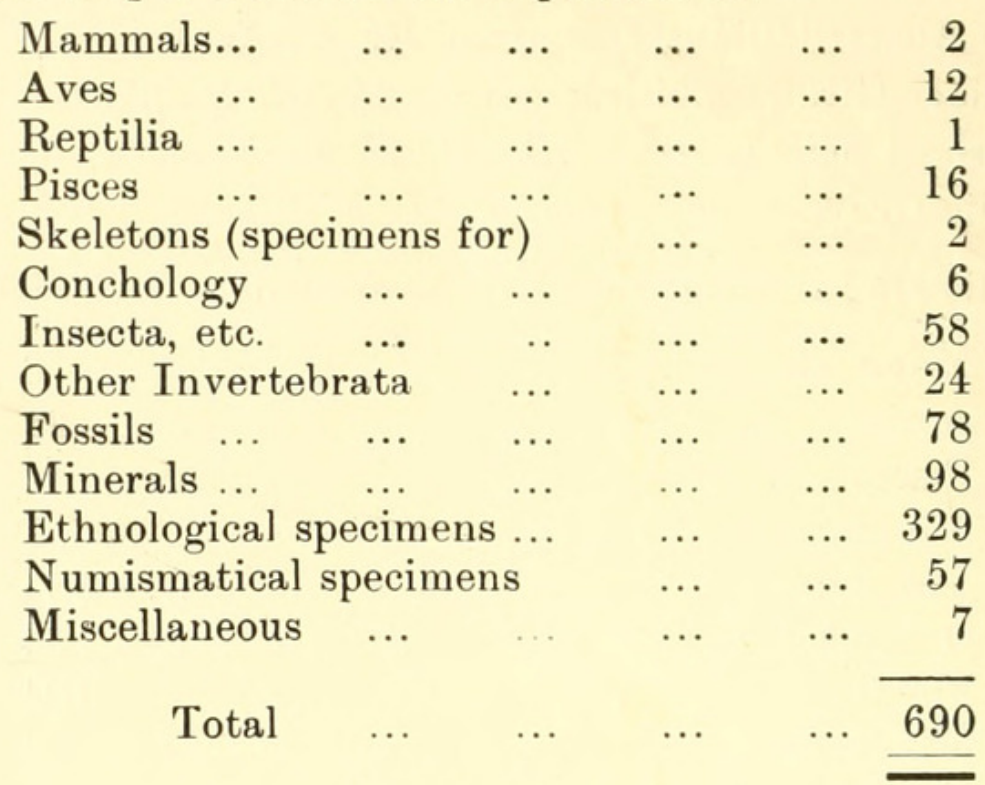

Publications.

The third part of Memoir Iv., dealing with the "Scientific Results of the Trawling Expedition of H.M.C.S. 'Thetis,' 1898," was published on 26th February. This part contains the Crustacea, Part 2, comprising the Isopoda, Part 1, by Mr. T. Whitelegge.

Of our "Records," Parts $1-4$ of Vol. Iv., were published as follows:-

$$
\begin{aligned}
& \text { Part 1, on 29th March. } \\
& \quad, \quad 2 \text {, on } 20 \text { th December. } \\
& , \quad 3 \text {, on } 29 \text { th July. } \\
& , \quad 4 \text {, on 28th August. }
\end{aligned}
$$

The fourth part was devoted to the Curator's Annual Report for 1900. The papers comprising the other parts will be noticed in their proper places.

After a good deal of trouble, chiefly owing to the difficulty of obtaining suitable paper, Part I. of Mr. A. J. North's "Special Catalogue of the Nests and Eggs of Birds found breeding in Australia and Tasmania," was published on 11th June. The excellence of this work, both in matter and style of production, speaks for itself, and hardly needs comment from me.

The scientific papers, official and unofficial, prepared by the Museum Staff, and published during 1901, are as follows:-

Etheridge, R., Junr.

1. Cone-like Stroboli, attached to a Phyllotheca-like foliage. Aust. Mus. Rec., Iv., 1, 1901, pp. 1-4, pls i. and ii.

2. Ctenostreon pectiniformis, Schlotheim, an Australian Fossil. Aust. Mus. Rec., IV., 1, 1901, pp. 13 -16, pl. iii. 
3. Occasional Notes:-I. Aperture of Conularia. Aust. Mus. Rec., Iv., 1, 1901, p. 52.

4. Lingula associated with Lepidodendron. Aust. Mus. Rec., IV., 3, 1901, pp. 119-120.

5. [Annual] Report [of the Curator] for the Year 1900. Aust. Mus. Rec., Iv., 4, 1901, pp. 145 - 174, pls. xx. - xхvi. (Ethnological and Historical Notes, pp. 164 and 168).

6. Additional Notes on the Palæontology of Queensland, Part 2. Bull. Geol. Surv. Queensland, 13, 1901, pp. 37, pls. i.-iv.

7. Notes on Fossil Plants from the Saint Lucia Coalfield, Enseline River, Zululand.

1st Ann. Report Geol. Survey Natal and Zululand (W. Anderson), 1901, pp. $67-76$, pl. xiii.

\section{Hedley, Charles.}

1. Some New or Unfigured Australian Shells. Aust. Mus. Rec., Iv., 1, 1901, pp. $22-27$.

2. A Revision of the Types of the Marine Shells of the "Chevert" Expedition.

Aust. Mus. Rec., Iv., 3, 1901, pp. 121 - 130, pls. xvi-xvii.

3. Studies on Australian Mollusca, Parts III. and IV.

Proc. Linn. Soc. N.S.W., xxv., 4, 1900, pp. $721-732$, pl. xlviii.; xxvi., 1, 1901, pp. 16-25, pl. ii.

4. The Marine Woodborers of Australasia and their Work.

Proc. Aust. Assoc. Adv. Sci., vilı., 1901, pp. $237-255$, pls. vii.- $\mathrm{x}$.

North, A. J.

1. Nests and Eggs of Birds found breeding in Australia and Tasmania.

Spec. Cat. Aust. Mus., I., 1, pp. 1 - 36, pls. i., ii.

2. Description of a New Species of Crow

Vict. Nat., xviI., 9, 1901, p. 170.

3. Additions to the Geographical Distribution of Australian Birds.

Vict. Nat., xvir., 10, 1901, pp. $187-188$.

4. Description of a New Species of the Genus Malurus.

Vict. Nat., xviri., 2, 1901, pp. $29-30$.

5. The Destruction of Native Birds in New South Wales.

Aust. Mus. Rec., IV., 1, 1901, pp. $17-25$.

Rainbow, W. J.

1. Notes on the Architecture, Nesting-habits, and Life-histories of Australian Araneidæ, based on specimens in the Australian Museum. Parts I., II.

Aust. Mus. Rec., Iv., 1 and 3, 1901, pp. 5-12, $135-142$. 
Waite, Edgar R.

1. Studies in Australian Sharks, with Diagnosis of a New Family. Aust. Mus. Rec., Iv., 1, 1901, pp. 28-35, pl. iv.

2. Additions to the Fish-fauna of Lord Howe Island, No. 2. Aust. Mus. Rec., IV., 1, 1901, pp. $36-47$, pls. v.-viii.

3. A Description of Macropus isabellinus, Gould. Aust. Mus. Rec., Iv., 3, 1901, pp. 131 -134, pls. xviii.-xix.

4. Occasional Notes:-II. Fishes. Aust. Mus. Rec., Iv., 1, 1901, pp. 53-54.

5. Occasional Notes:-IV. Uronycteris cephalotes, Pallas. Aust. Mus. Rec., IV., 3, 1901, p. 144.

Whitelegge, Thomas.

1. Description of a new Hermit Crab (Calcinus imperialis), from Lord Howe Island. Aust. Mus. Rec., IV., 1, 1901, pp. $48-51$, pl. ix.

2. Report on Sponges from the Coastal Beaches of N. S. Wales. Aust. Mus. Rec., Iv., 2, 1901, pp. 55-118, pls. x-xv.

3 Occasional Notes:-III. Limnoria lignorum, Rathke-a

Wood-borer: Its occurrence in Sydney Harbour. Aust. Must. Rec., IV., 3, 1901, p. 143.

4. Scientific Results of the Trawling Expedition of H.M.C.S.

"Thetis." Crustacea, Part II : Isopoda, Part I. Aust. Mus. Mem., IV., 3, 1901, pp. $201-246$.

\section{Information Disseminated.}

Information of a scientific and practical nature was supplied to all members of the public who applied either in writing or person, and every facility was afforded to students and schools who chose to avail themselves of the afternoon in each week set apart for study.

The following Public Officers were supplied with information:-

1. Adjutant, R.A.A., Victoria Barracks-Examination and report on certain military stores (cartridge bags, etc.) destroyed by insects (W. J. Rainbow).

2. Fishery Commissioners of N.S. Wales-(a) Examination of Oysters infested with Polydora ciliata, Johnston, and Report (T. Whitelegge); (b) Identification of Fishes (E. R. Waite).

3. Assistant Government Geologist, Launceston, TasmaniaDetermination of Silurian fossils (Curator).

4. Berry School of Arts Museum (T. R. Lewers, Hon. Curator)Determination of local Permo-Carboniferous Fossils (Curator)

5. Board of Health, Sydney- $(a)$ Determination of Ticks; $(b)$ Determination of Parasitic Arachnoidea (W. J. Rainbow). 
6. Assistant Entomologist, Department of Agriculture, Sydney (E. Gurney) - Re Spiders of genus Lycosa destroying lawns by tunnelling ( W. J. Rainbow).

7. Librarian, Geological Survey of Queensland, Brisbane (C. F. V. Jackson)-Instruction in Library work and arrangement (Curator and Librarian).

8. Government Veterinary Surgeon(J. D. Stewart) - Re Parasitic Arachnoidea (W. J. Rainbow).

9. Inspector of Stock, Glen Innes (J. St. Clair)-Points of distinction between pelts of Rabbits and Hares (E. R. Waite).

10. Secretary, Zoological Society of N. S. Wales-Post-mortem on Lion (Taxidermists, etc.)

11. Veterinary Surgeon, Zoological Society of N. S. Wales (Capt. A. P. Gribben)-Microscopical and chemical examination of Lion's blood (T. Whitelegge and C. Anderson).

12. Lecturer in Geology and Palæontology, Adelaide University (Rev. W. Howchin)-Affinities of peculiar organisms from Cambrian of S. Australia (Curator and T. Whitelegge).

13. Director, California Academy of Science Museum, San Francisco (C. Keeler)_Explaining Museum Collections and our methods of management (Staff).

14. Editor, "Town and Country Journal," Sydney-Answers to correspondents' queries (Staff).

15. Editor, "Stock and Station Journal," Sydney-Generation of Marsuipials, and references to literature bearing thereon (Curator and E. R. Waite).

16. Curator, Tasmanian Museum, Hobart (A. Morton)-Identification of Permo-Carboniferous Platyschismce (Curator).

17. Imperial Austro-Hungarian Consul (Dr. A. Scheidel)-Identification of Pacific Spears and Arrows (Curator).

The more important items of information supplied to members of the public were:-

1. Mr. F. Conway-Identification of Moths, and Notes on their habits (W. J. Rainbow).

2. Mr. J. H. Maiden-Information re Capt. James Cook, R.N. (Curator).

3. Mr. H. J. Carter, M.A.-Determination of Coleoptera (W. J. Rainbow).

4. Miss M. Lodder-Determination of Port Jackson Shells (C. Hedley).

5. Mr. G. Sweet, Melbourne-References to literature of Native Implement Quarries and Workshops (Curator).

6. Mr. F. G. Whibley, of Noutai, Ellice Group-Instruction in collecting and preserving (Staff).

7. Directors, Pacific Islands Co., Sydney-Commercial character of Sponges from Manihiki (T. Whitelegge). 


\section{Transfer of Specimens.}

The only transfers of specimens to other public bodies within the State were:-

1. Technological Museum, Sydney- $(a)$ Additional metallurgical specimens; (b) Building stone blocks, showing tooling; (c) Twenty-four glazed boxes, displaying alluvial gold-field deposits; (d) Large photographs of Mining Machinery.

2. Trustees, Art Gallery, Sydney-Portraits of Her late Majesty the Queen and the Prince Consort.

3. Public School, Moss Vale-Collection of miscellaneous Shells, to assist in forming a School Collection (458 specimens, comprising 108 genera and 200 species).

\section{Spirit Collections.}

The store collections are all in good order, and were carefully looked after. Two important alterations were effected. Our tanks have hitherto been of wood, and leaked, notwithstanding all precautions to the contrary. We are now trying the experiment of lining these wooden tanks with thin sheet lead, and coating the latter with a composition; it is, however, intended in the future to replace the whole by slate tanks, and one has already been made and taken into use as an experiment.

Twenty-four gallons of old spirit were redistilled during 1901 . The still was also made use of in the preparation of distilled water for the Chemical Laboratory.

\section{TAXIDERMists.}

\section{(Messrs. J. A. Thorpe and R. Grant.)}

As in former years, the Taxidermists were charged with the supervision of the Skin Collections, both exhibited and in store. The Assistant Taxidermist also aided greatly in keeping clean the interior of the Palæontological and Mineralogical cases.

The re-mounting of the Australian Birds was continued from the previous year, under my personal supervision, as opportunity would permit; and by May the remainder of those displayed on the east side of the gallery, including the Ducks, Waders, Gulls, Petrels, Grebes, and Penguins, was completed, and a commencement was made with the Hawks on the west side.

A very fine series of Paradisea, comprising twenty birds, was set up for Mrs. E. E. Kolbe, of Rallum, New Britain, in our Taxidermists' best style. This work was performed in return for many valuable donations made by Mrs. Kolbe.

Two Sea Trout (Salmo trutta, Linn.), and a Sock-eye Salmon (Onchorhynchus nerka, Walb.), were mounted for the Fishery Commissioners of N. S. Wales, and gave every satisfaction to 
that body; and two examples of the latter fish were similarly treated for the Amateur Fisherman's Association of N. S. Wales.

An Isabelline Kangaroo (Macropus isabellinus, Gould), was mounted, and also a Chimæra (Chimcera ogilbyi, Waite). Both of these were additions to our collections. Some time was also given to the preparation of eighteen mounted Marsupials for exchange with the Zoological Museum of the Imperial Academy of St. Petersburg.

The following is a record of the work performed in the workshop during the year:-

\begin{tabular}{c|c|c|c|c|c|c}
\hline Nature of Work. & Mammals & Birds. & $\begin{array}{c}\text { Nest } \\
\text { Groups. }\end{array}$ & Fish. & Reptiles. & Totals. \\
\cline { 6 - 7 } $\begin{array}{c}\text { New skins prepared } \\
\text { and made up..... }\end{array}$ & 98 & 161 & $\ldots$ & 17 & $\ldots$ & 276 \\
$\begin{array}{c}\text { New skins mounted } \\
\text { for Museum cases }\end{array}$ & 3 & 35 & 9 & 15 & 18 & 80 \\
$\begin{array}{c}\text { Old skins restored ... } \\
\text { Old exhibited speci- } \\
\text { mens restored ... }\end{array}$ & 55 & 25 & $\ldots$ & 13 & $\ldots$ & 38 \\
$\begin{array}{c}\text { New groups mounted } \\
\text { for Museum cases }\end{array}$ & $\ldots$ & 40 & $\ldots$ & $\ldots$ & $\ldots$ & 128 \\
\hline Totals ............ & 156 & 331 & 12 & 45 & 18 & 562 \\
\hline
\end{tabular}

Articulators.

(Messrs. H. Barnes, Junr., and A. R. Taylor).

The Articulators continued in charge of the Osteological cases for cleansing and disinfecting purposes.

The disarticulating, cleaning, and remounting of previously exhibited specimens was continued, eight being so treated. The disarticulated comparative series of bones was increased by one hundred and sixty-eight specimens.

Eighty-six bird sternums were cleaned and repaired, and eightythree were mounted for exhibition, as the commencement of a "Structural Series."

The more important skeletons prepared and mounted, requiring more than ordinary care, were those of the Chimæra (Chimcera ogilbyi, Waite), a Native Companion (Grus australasianus, Gould), the Luvaru (Luvarus imperialis, Raf.), and a Death Adder (Acanthopis antarctica, Shaw). In consequence of the Luvaru arriving in a salted and half-dried state, thorough maceration could not be effected, necessitating far more manual work and dexterity than is usually the case. The skeleton of the Native Companion is a very fine piece of work, the extraordinary ossification that the tendons had undergone requiring very delicate treatment. 
During the year 446 specimens were handled, as follows:-

\begin{tabular}{|c|c|c|c|c|c|}
\hline Nature of Work. & Mammals & Birds. & Fishes. & Reptiles. & Totals \\
\hline New skeletons prepared ...... & 15 & 33 & 1 & 2 & $5 l$ \\
\hline New skeletons mounted ...... & 3 & 10 & 1 & 1 & 15 \\
\hline $\begin{array}{l}\text { Old exhibited skeletons re- } \\
\text { mounted or cleaned ........... }\end{array}$ & 8 & & $\cdots$ & $\cdots$ & 8 \\
\hline Disarticulated bones prepared & 168 & . & .. & $\cdot$ & 168 \\
\hline Disarticulated bones mounted & 34 & .. & 1 & & 35 \\
\hline Shoulder girdles prepared $\ldots$ & $\ldots$ & 86 & $\ldots$ & & 86 \\
\hline Shoulder girdles mounted $\ldots$ & $\cdots$ & 83 & $\cdots$ & & 83 \\
\hline Totals ......... & 228 & 212 & 3 & 3 & 446 \\
\hline
\end{tabular}

Formatori.

(Messrs. H. Barnes, Jun., and A. R. Taylor.)

After the renovation of the Workshops in connection with the building of the first half of the South Wing, our series of plaster moulds was replaced on the shelves of the Casting and Moulding Room in its former order.

At the request of the Government Geologist (Mr. E. F. Pittman, A.R.S.M.), reproductions of the Gilgoin Meteorites, Nos. 2 and 3 , weighing respectively $55 \frac{1}{4} \mathrm{fbs}$. and $37 \mathrm{fbs}$, were prepared for the Geological Survey Branch of the Department of Mines and Agriculture, and copies were secured for our cases. Copies of our Nocoleche Meteorite were also prepared and forwarded as exchanges to the School of Mines and Industries of South Australia, in Adelaide, and to the Technological Museum, Sydney.

I derived considerable assistance from the Formatori in the preparation of plaster and jelly reliefs of various natural impressions or "casts," of fossil organic remains.

The full return of work performed is as follows :-

\begin{tabular}{|c|c|c|c|c|c|}
\hline Nature of Work. & Skeletons. & Fossils. & Minerals. & Ethnology. & Totals. \\
\hline New moulds prepared & 10 & & 2 & 7 & 19 \\
\hline New casts made $\ldots . .$. & 10 & 5 & 7 & 7 & 29 \\
\hline $\begin{array}{l}\text { Reproductions from } \\
\text { old moulds }\end{array}$ & & & 1 & & 1 \\
\hline New casts coloured .... & $\ddot{10}$ & $\cdots$ & 3 & 5 & 18 \\
\hline Totals... & 30 & 5 & 13 & 19 & 67 \\
\hline
\end{tabular}




\title{
Photographer.
}

\author{
(Mr. H. Barnes, Junr.)
}

We are now utilising in a very great measure our photographic appliances for the production of the plates of the Museum publications. It may not be out of place to mention that nearly all the negatives for the very fine illustrations of nests and eggs adorning Mr. A. J. North's 'Catalogue of the Nest and Eggs of Birds found breeding in Australia and Tasmania' were prepared either by Mr. North himself or by Mr. Barnes, in the field and studio respectively. The Trustees are particulafly fortunate in possessing as members of the staff no less than four accomplished photographers, Messrs. T. Whitelegge, A. J. North, E. R. Waite, and H. Barnes, Junr. The collection of negatives now amounts to upwards of 1,945 .

Thirty-five prints were presented to the Trustees during 1901, chiefly of an Ethnological nature. Many of these represented scenes in Ocean and Pleasant Islands, taken and given by Mr. F. Danvers Power.

The following is a return of the work performed :-

\begin{tabular}{|c|c|c|c|c|c|c|c|c|c|}
\hline Nature of Work. & 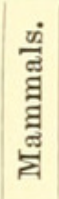 & 夠 & 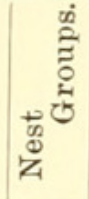 & 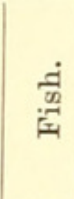 & 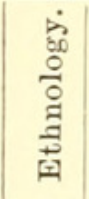 & 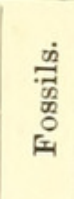 & 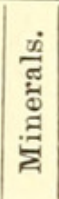 & 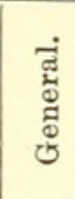 & 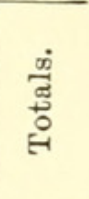 \\
\hline New negatives prepared.. & $\cdots$ & 3 & 9 & 8 & 15 & 11 & . & $\ldots$ & 46 \\
\hline New prints prepared ............ & 5 & 9 & 56 & 16 & 26 & 23 & .. & $\ldots$ & 135 \\
\hline Prints from old negatives ...... & ... & $\ldots$ & .. & $\cdots$ & $\cdots$ & $\cdots$ & 2 & & 2 \\
\hline Prints mounted ................. & 4 & 4 & 14 & 5 & 28 & 8 & . & 35 & 98 \\
\hline Letter.press prints mounted ... & $\cdots$ & $\cdots$ & $\cdots$ & 38 & $\cdots$ & $\cdots$ & $\ldots$ & $\cdots$ & 38 \\
\hline Totals & 9 & 16 & 79 & 67 & 69 & 42 & 2 & 35 & 319 \\
\hline
\end{tabular}

Artificers (including Carpentry and Smith's-work).

(Messrs. R. Barnes and B. Lucas.)

A large amount of varied work was carried out in the Artificer's workshop, both in wood and metal.

Under Mr. R. Barnes' superintendence, the magnificent Chinese Cheval-glass from Pekin, was safely erected, and now forms one of our most attractive exhibits.

Amongst some of the more important work may be mentioned :-

1. Cabinet for a collection of Chinese coins.

2. Fitting drawers of Numismatic table-cases with false bottoms.

3. Four Card-catalogue cabinets. 
4. Twelve picture frames for explanatory drawings and photographs to accompany specimens.

5. Seventy-one wooden Fish family label frames.

6. Twelve metal label and notice frames for general purposes.

7. Twelve collecting tanks and metal mountings for same.

8. Brass edge bindings to Museum Registers.

9. Five hundred and eight stands of various sizes for specimens.

10. Twenty-three stands for large Mammalia repolished.

11. Galvanised iron and zinc trays for use of Articulators.

12. Additional shelving in workshops.

13. Additional step throughout wall cases of Fish gallery.

14. General locksmith work throughout Museum.

15. Repairs to printing machine.

\section{Compositor and Printer.}

(Mr. J. W. Woodhead.)

During 1901, 15,215 labels were prepared, composed and printed, showing an increase of 4,728 over those of 1900 . These were distributed as follows :-

\begin{tabular}{|c|c|c|c|c|}
\hline Mammalia & $\ldots$ & $\ldots$ & $\cdots$ & 12 \\
\hline Reptilia... & $\ldots$ & $\ldots$ & $\ldots$ & $\ldots$ \\
\hline Aves $\ldots$ & $\ldots$ & $\ldots$ & $\ldots$ & 126 \\
\hline Pisces $\ldots$ & $\ldots$ & $\ldots$ & $\ldots$ & .. 1,597 \\
\hline Skeletons & $\ldots$ & $\ldots$ & $\ldots$ & 341 \\
\hline Insecta, etc. & $\ldots$ & $\ldots$ & $\ldots$ & $\ldots$ \\
\hline Conchology & $\ldots$ & $\ldots$ & $\ldots$ & $\ldots$ \\
\hline Other Invertel & rata & $\ldots$ & $\ldots$ & $\ldots$ \\
\hline Ethnology & $\ldots$ & $\ldots$ & $\ldots$ & $\ldots$ \\
\hline Mineralogy & $\ldots$ & $\ldots$ & $\ldots$ & $\ldots$ \\
\hline Palæontology & $\ldots$ & $\ldots$ & $\ldots$ & $\ldots$ \\
\hline Numismatics & $\ldots$ & $\ldots$ & $\cdots$ & $\cdots$ \\
\hline Historical & $\ldots$ & $\ldots$ & $\ldots$ & $\ldots$ \\
\hline Library .... & $\ldots$ & $\ldots$ & $\ldots$ & 680 \\
\hline General ... & $\ldots$ & $\ldots$ & $\ldots$ & $\ldots 10,436$ \\
\hline & & & & 15,21 \\
\hline
\end{tabular}

(Mr. J. W. Woodhead.)

In my last year's Report I referred to the fact that a commencement had been made with book-binding on the premises, chiefly confined to official forms and records. This work has quietly and unostentatiously progressed, the following being some of the more important items :-

1. Three books, balance sheets and correspondence list.

2. One book, Annual Report (type-written) for presentation to His Excellency the State Governor, 
3. Ten half-bound, and one quarter-bound books.

4. Five file-cases.

5. Three refil cases.

6. Fifteen scribbling blocks.

7. Sixteen portfolios.

8. Two hundred and ten Library catalogue cards, cut to pattern.

9. Four pamphlets, "Catalogue of Shells."

10. Five pamphlets, "List of N. S. Wales Sponges."

11. Three "Geographical Gazetteers," indexed.

\section{Mammalia.}

\section{(Mr. E. R. W AITE, Assistant-in-Charge.)}

$\mathrm{Mr}$. Waite reports that from an exhibition point of view nothing more can be effected, and pending the acquisition of additional space all that can be done is to keep the specimens in good order, and in a state of cleanliness. Two important additions were, however, made, a skin of Macropus isabellinus, Gould, obtained by exchange from the Perth Museum, and a fine head of a Bison (Bos americanus, Gmel.). The former was described in detail by Mr. Waite, ${ }^{2}$ who showed that the supposed identity of the mutilated skin, all previously known of this Kangaroo, with the skull termed Macropus magnus, by Owen, is untenable. The greatest rarity amongst our indigenous fauna, obtained during the year, was a further specimen of Sminthopsis crassicaudata, Gould, presented by Mr. G. H. Doyle. Of the one hundred and four described species of Australian Marsupials, this Museum now possesses ninety-two, and examples of the whole of these are mounted and exhibited in the cases devoted to the Marsupialia. The range of a rare Bat (Uronycteris cephalotes, Pallas), hitherto only known from Cape York, was extended by Mr. Waite, ${ }^{3}$ by specimens received from the Bloomfield River, near Cooktown, Queensland, and Alstonville, on the Richmond River, in this State.

As in past years, Messrs. J. C. Jansen and J. Stringer, Live Animal Dealers of this city, were most liberal in their donations of Marsupials, chiefly Wallabies. Again, the Council of the N. S. Wales Zoological Society, with its usual liberality, transferred to us animals that died in their Gardens, including a Leopard (Felis pardus, Linn.), a Grivet Monkey (Cercopithecus sabceus, Linn.), a Sacred Baboon (Papio hamadryas, Linn.), a Dusky Langur (Semnopithecus obscurus, Reid) and a Japanese Bear (Ursus japonicus, Schleg.). From the Council was also purchased a fine five-year old Lion, bred in the managerie, measuring nine feet nine inches from nose to tail-tip, or six feet nine inches from nose to tail-base.

2 A Description of Macropus isabellinus, Gould.-Rec. Aust. Mus., iv., 3, 1901, pp. $131-134$, pls. xviii. - xix.

3 Waite-Uronycteris cephalotes,Pallas-Rec. Aust.Mus., iv., 3, 1901, p. 144. 
The dogs brought to Sydney en route for the German Antarctic Expedition, were of great interest to us; and through the courtesy of the Chief Inspector of Stock (Mr. Alex. Bruce), Mr. Waite and myself were afforded an opportunity of examining them. A dog dying during the stay of the pack in Sydney, the Chief Inspector was good enough to forward the carcass to the Museum, with the approval of the Expedition's Sydney agents, Messrs. Lohmann and Oo.

The specimens received in this Section during 1901, were:-by donation, forty-one; exchange, eight; purchase, two; and collection two.

Aves.

(Mr. A. J. North, Assistant-in-Charge).

Mr. North reports as follows:- "Relieved of the duties appertaining to the registration of Ethnological, Numismatical, and Historical specimens, that I have performed for the past nine years, I was enabled to devote my time entirely to this Section. The acquisitions totalling one-third more than during the previous year, my attention was divided between the ordinary routine or administrative work-such as registration, determination, and labelling of specimens-and the preparation of MS. for the Special Catalogue, 'Nests and Eggs of Birds found breeding in Australia and Tasmania.' In the preparation of the latter work, I must here acknowledge the valuable assistance received by the loan of numerous specimens for comparison and examination from the Directors of the South Aus tralian Museum, Adelaide, and the Queensland Museum, Brisbane. To a less degree, similar help was also received from Dr. A. M. Morgan, Dr. W. Macgillivray, Mr. E. Ashby, Mr. G. A. Keartland, and Mr. G. Savidge. After vexatious delays, through difficulty in obtaining suitable paper by the printer, a small part of the Catalogue was issued about the middle of June. The requisite paper for further printing was not received from London until towards the close of the year. Field work was paid more attention to than has been done for a long while past, with the result that numerous additions were made to the collection. Photographs of nests in situ were taken, and much useful information obtained of the life-histories of some of the rarer species. An ever increasing correspondence on ornithological subjects, exhibits the growing interest taken in our Australian avifauna. Small collections of birds and eggs were determined, and eighty-four species of birds' eggs were named for the Director of the Athens Museum. Among specially interested visitors and co-workers might be mentioned the late Mr. Lionel W. Wiglesworth, a former colleague of Dr. A. B. Meyer, of the Dresden Museum, and joint author with him of the 'Birds of Celebes.' Mr. Wiglesworth spent about a fortnight in Sydney, and was particularly interested in the collection of Polynesian bird-skins." 
The Council of the New South Wales Zoological Society presented a number of specimens from their menagerie, amongst which may be mentioned a fine Blue and Yellow Macaw (Ara ararauna, Linn.), and a Ruddy Sheldrake(Casarca rutila, Pallas). Mr. G. Savidge, of Copmanhurst, who has been a long and constant contributor, forwarded Heine's Ground Thrush (Geocichla heinii, Cabanis), and two nestling Delicate Owls (Strix delicatula, Gould). Mr. Summerhays Jeboult presented several birds obtained about Randwick and Botany, including a Little Water Crake (Porzana palustris, Gould), and a Little Bittern (Ardetta minuta,Linn.). From Mr. T. F. Josephson we received a Pectoral Rail (Hypotcenidia philippensis, Linn.); from Mr. S. Harvey, a beautiful White Goshawk (Astur nova-hollandice, Gmel.); from Mr. E. J. Cook, a very fine example of the Wedge-tailed Eagle (Aquila audax, Lath.), from Jenolan; from Mr. F. H. Galbraith, a Red-necked Avocet (Recurvirostra novce-hollandice, Vieill.); from Mr. J. Stein, a Powerful Owl (Ninox strenua, Gould). Our most constant and regular contributor, Mr. H. Newcombe, forwarded three Pectoral Rails, a White Ibis (Ibis molucca, Cuvier), and other birds. A rarity reached us, and a welcome addition to our Reference Collection, from Uralla, a Black-eared Cuckoo (Misocalius palliolatus, Lath.); and from Fiji, the White-breasted Wood Swallow (Artamus mentalis, Jard.), where it is said to feed on the Bot-fly. From the little-visited Nawado, or Pleasant Island, Messrs. F. Danvers Power and E. A. Stephen brought us Rehse's Reed Warbler (Arcocephalus rehsei, Finsch).

A very interesting addition to our series of nests of native birds, consisted of the nest and three nestlings in down of the Tawny-shouldered Frog Mouth (Podargus strigoides, Lath.), presented by Mr. R. Lennard; a nest of the Yellow-breasted Scrub Wren (Sericornis citreogularis. Gould), was forwarded by $\mathrm{Mr}$. H. S. Mort; the nest and eggs of the White-fronted Epithianura (E. albifrons, J. \& S.), by Mr. A. M. N. Rose; and from the far north, Mr. Bertie L. Jardine, of Cape York, sent the nest and two eggs of the Masked Bush Warbler (Gerygone personata, Gould). The largest contributors of nests, however, were Mr. E. H. Lane and Mr. North personally. The former forwarded seven from the neighbourhood of Orange, and the latter collected fifteen in the home district.

For some time past I have made strenuous efforts to obtain the nests and eggs of birds acclimatised in Australia. We so far possess those of the Sparrow (Passer domesticus, Linn.), the Indian Spotted Dove (Turtur suratensis, Gmel), the Starling (Sturnus vulgaris, Linn.), and the Greenfinch (Fringilla chloris, Linn.)

A most acceptable gift was received from Dr. P. Herbert Metcalfe, Resident Medical Officer at Norfolk Island, consisting 
of a collection of birds' eggs made there by him. On this series Mr. North reports:- "This collection, the result of over twentyfive years' labour, contains the eggs of all but two birds that are known to inhabit or frequent the island. It is particularly rich in sea-birds' eggs, the series of Sooty Terns (Sterna fuliginosa, Gmelin), alone numbering over one hundred distinct varieties. As each specimen is perfect, and its history known, the value of the collection is inestimable."

From Mr. H. F. Marr the eggs of the Comb-crested Parra (Parra gallinacea, Temm.), were received; and from Mr. G. Savidge, twenty-seven other sets from the Copmanhurst District.

A matter that requires urgent attention on the part of the State Governments is that of the wilful destruction of our native birds, not only the highly plumaged forms, but even the humbler and more sombre-hued of our feathered friends-the former for the sake of their brightly-coloured feathers in their commercial aspect, the latter, too often, from pure wantonness. On this subject Mr. North has lately published some observations ${ }^{4}$ that are well worth perusal.

It was hoped that the passing of the "Birds' Protection Act of 1893," (56 Vict. No. 18), would have had a beneficial effect in preserving our birds, but it appears to have become a dead letter, indeed the appended schedules, as a means of legal bird identification, are far too indefinite. Quite recently an Amended Bill has passed the Legislature, the " Birds' Protection Act of 1901 (1 Edw. vii., No. 26), which will probably share the same fate.

The following suggestions are offered as a means of rendering the Act more operative:-

1. Instruct the police to prosecute all persons, who have not a permit, for shooting birds that are protected under the Act in the close season.

2. In the country districts let especial attention be paid to persons who shoot birds for profit, such as the Regent Bower-bird, the Rifle-bird, and Lyre-bird, and all game birds and waterfowl.

3. Near cities instruct the suburban police to prosecute all offenders against the Act. (The principal offenders are boys and youths, who shoot on Saturdays and holidays).

4. Let due notice be given in the newspapers, just prior to any holiday occurring in the close season, that persons shooting protected birds will be rigorously prosecuted.

5. Place in a conspicuous position on every railway-station, post-office, court-house, and school in the State, a large poster of the Birds' Protection Act.

6. Let teachers instruct the children in the public schools the harm they are doing in killing birds and robbing nests.

It may be interesting to note that of the seven hundred and sixty (approximately) known species of Australian birds, our collection contains six hundred and eighty-seven. Of the latter,

${ }^{4}$ North-The Destruction of Native Birds in New South Wales.Aust. Mus. Rec., Iv., 1, 1901, pp. 17-25. 
five hundred and sixteen species are mounted and exhibited, and represented by eighteen hundred and forty-eight specimens. Of foreign birds (i.e., those not actually indigenous), there are two thousand three hundred and fifty-one mounted and exhibited specimens, of which three hundred and fifty-four are frequenters of the South Pacific.

During 1901, four hundred and forty-nine birds were obtained by donation, twenty-one by exchange, twelve by purchase, and one hundred and thirty-one were collected.

\section{Reptilia AND Batrachia.}

(Mr. E. R. WAIte, Assistant-in-Charge).

Mr. Waite reports that owing to the transfer of the Sharks to the new Fish Gallery, a re-arrangement of the Reptiles became possible. This was effected by giving the Snakes a wall-case to themselves, and expanding the other groups over the space so vacated.

The most important presentation was a collection of Snakes and Lizards, from New Britain, by Dr. J. F. Flashman; other series were forwarded from West Australia, by Mr. W. D. Campbell; and Ocean and Pleasant Islands, by Messrs. F. Danvers Power and A. E. Stephen.

As a result of a change in the receptacles for storage in the Spirit House, a large number of old specimens were registered.

In the Reptilian cases, as exposed to public view, there are the following specimens :-

\begin{tabular}{|c|c|c|c|c|}
\hline Group. & Australian. & Pacific. & Foreign. & Total. \\
\hline Lizards & 132 & 23 & 112 & 267 \\
\hline Snakes................. & 74 & 4 & 19 & 97 \\
\hline Frogs, etc. .................... & 44 & 41 & 75 & 150 \\
\hline Crocodiles $\ldots \ldots \ldots \ldots \ldots \ldots$ & 17 & $\ldots$ & $\ldots$ & 17 \\
\hline Total $\ldots \ldots \ldots \ldots \ldots$ & 267 & 68 & 206 & 541 \\
\hline
\end{tabular}

In this section, during 1901 , seventy-one specimens were received by donation, one by purchase, and six were collected.

\section{Pisces.}

(Mr. E. R. W AIte, Assistant-in-Charge).

"The chief work of the year," says Mr. Waite, in the sections under his control, "was effected amongst the Fishes, by continuing the mounting and placing of the specimens in the new Gallery, the preparation of labels, all of which were printed, including family labels, and the preparation of a card catalogue for working 
purposes. The Sharks were removed from the central vestibule of the upper Main Hall to the Fish Gallery. The Regalecus glesne, Asc., and Trachypterus jacksoniensis, Ramsay, were separately cased; coloured plaster reproductions of food fishes were arranged in a separate case on the stair landing outside the gallery entrance; and copies of our published plates of Fishes, from my drawings, were framed and placed on the walls of the same."

Much information was supplied to enquirers, and particularly to Mr. Tokichi Nishikawa, Zoologist to the Imperial Fishery Commission of Japan; and to the Fishery Commissioners of N. S. Wales.

Amongst the more important results of the year's work, Mr. Waite demonstrated that the Dusky Dog-fish, or "Blind Shark," (Hemiscyllium modestum, Günther), is ovoviviparous, also that the Wobbegong (Orectolobus barbatus, Gmelin, sp.) brought forth its young in a similar manner. ${ }^{5}$

In my Report for 1900, I alluded to Mr. Waite's researches amongst the Fishes of Lord Howe Island. These were continued as collections came to hand, with the result that No. 2 of the "Additions" has been published. ${ }^{6}$ Amongst other interesting records, he described a new three-banded Chcetodus (C. tricinctus, Waite), and figured Ogilby's Monacanthus howensis.

The donations during 1901 were larger than usual in past years. A very acceptable present of fish from New Britain was received from Dr. J. F. Flashman, comprising ten species; and another of Rifle-fish (Toxotes chatareus, Ham. Buch.) was sent from the Ulmsley River, Queensland, by Mr. G. H. Blakemore. These are caught with rod and line, and grasshopper bait, and are attracted by dropping stones into the water. An interesting variety of the Black Sole (Synaptura nigra, Macl.), in which the underside, for the most part, is coloured like the upper, was presented by Mr. N. Aceglav.

Mr. J. D. Ogilby presented a general collection, comprising one hundred and forty-five specimens (fifty-three species), viz.:eighteen European, ten American, and twenty-five Australian. An example of a Saw-fish (Pristis zysron, Bleek.), was given by Mr. J. E. Chinery, a city fishmonger, measuring eight feet six inches over all, the saw being two feet seven inches long.

The piscatorial result of Mr. C. Hedley's visit to the inlying portions of the Barrier Reef, was the acquisition of thirty-four much needed fishes from northern waters.

5 Waite-Studies in Australiaa Sharks, with Diagnosis of a New Family.-Aust. Mus. Rec., IV., 1, 1901, pp. 28-35, pl. iv.

6 Waite-Additions to the Fish-fauna of Lord Howe Island, No. 2.Ibid., pp. 36-47, pls. v. - viii. 
A most important addition, due to the forethought of a manyyears donor, Mr. J. A. Boyd, of Eden, reached us in the form of a Basking Shark (Cetorhinus maximus, Gunner.), taken off that place. It is the second record only, so far as we know, for Australia, the previous capture having been off the coast of Victoria. It is nine feet long.

At the close of the year, the exhibited Fish Collection numbered 1,112 specimens, either dry and mounted or in spirits.

The specimens received by donation during the year were two hundred and ninety-nine; by exchange forty-two; by purchase sixteen; and eighty-five were collected.

\section{Osteology.}

(Mr. E. R. WaIte, Assistant-in-Charge).

Three very important and interesting acquisitions were added to the Osteological series last year. A salted example of the Atlantic Luvaru (Luvarus imperialis, Raf.), was presented by the Fishery Commissioners. It was cast up on the bank of the river at Bermagui, N. S. Wales, and forms the first occurrence of the fish in the Pacific, so far as we know. From this, notwithstanding the salting process it had undergone, a very excellent skeleton was prepared.

For the first time a skeleton of the Chimæra or Ghost Shark (Chimcera ogilbyi, Waite), is present in the Museum, having been prepared from a fresh specimen, presented by Mr. A. G. Platé.

The third skeleton is a most remarkable instance of "tenostosis," or tendon ossification in a bird, a Native Companion (Grus australasianus, Gould), received from the Zoological Gardens.

A fine head of a Babirussa (B. babirussa, Linn.), from Pagoejaman, Celebes, was presented by Mr. E. V. Bensusan.

By purchase, the skull of a New Caledonian was procured, possessing an additional small and ill-developed molar in each lower ramus, four instead of three.

A commencement was this year made towards the exhibition of a Structural Osteological series, by mounting eighty-three shoulder-girdles of Birds.

Thirty-two specimens were received in all by donation; two were purchased; and six collected.

Insecta, Mrriapoda, and Arachnida.

(Mr. W. J. Rainbow, Assistant-in-Charge).

Mr. Rainbow reports that of the two new cabinets provided last year, many specimens were placed in that devoted to the Arachnida. The new case for Australian Moths is fully occupied already. The whole of the Australian Coleoptera and Life-histories 
exhibited were furnished with printed labels. Attention was then given to the Australian Moths, and the task of setting out specimens for exhibition was nearly completed. The systematic arrangement of the cabinet specimens of Australian Beetles was commenced, and incidentally with this, the duplicate series of the same. As the work of rearrangement proceeded, the specimens were cleaned and remounted to a uniform guage.

A fine collection of one hundred and seventy-one Beetles from the Weddin Mountains, was presented by Mr. H. W. Cox; another, of a hundred and four, from the neighbourhood of Sydney and the Blue Mountains, by Mr. H. J. Carter, M.A.; seventy-seven from the Fowler's Bay District, S. Australia, by Mr. R. T. Maurice, including the rare Stigmodera mniszechi, Saund.; examples of Mastochilus australasicus, Perch., infested with Mites (Aponomma ecinctum, Newm.), from the Tweed River, by Mr. J. Yardley.

Amongst the Butterflies and Moths presented, may be mentioned one hundred and ten from the New Hebrides, by the Rev. Dr. Annand; forty-six from the Blue Mountains and South Coast, by Mr. G. A. Waterhouse; and thirty-seven Moths from Kensington Downs, Queensland, by Mr. A. J. Ewen.

A small but most valuable collection of Indian Mosquitos from the N.W. Provinces of India, was presented by Major G. M. Giles, I.M.s. ; these will prove of great service to us in the future.

As illustrating the destructive work of Termites, two books, Dalziel's "British Dogs," completely riddled by these pests, were given by $\mathrm{Mr}$. O. H. M. Paine; and an interesting exhibit of the nest of a Praying Martis, with the insect and its young, was forwarded by Mrs. Hall, from Liverpool. A Scorpion (Charon australianus, L. Koch), new to our cases, was obtained by $\mathrm{Mr}$. C. Hedley at the Barron Falls, near Herberton, Queensland.

The exertions of Mr. J. C. Wiburd, one of the guides at Jenolan Caves, have been the means of adding no less than five hundred and thirteen Spiders to our already rich Arachnidian Collection, from the various caves and surrounding country at the locality mentioned, accompanied by a reticularian web, the work of an Amaurobius.

Mr. J. J. Walker, R.N., of H.M.S. "Ringarooma," contributed thirty-two Spiders from Freemantle and Port Lincoln, thirteen from other parts of the continent, and one hundred and eighty from the New Hebrides, Loyalty Islands, and New Caledonia. Of these, five are types, viz., Dicea bipunctata, Rainb.; D. regale, Rainb.; Leptodrassus insularus, Rainb.; Argyrodes antipodiana, Camb.; and A. walkeri, Rainb. Lycosa conosa, Rainb., was originally recorded from Santa Cruz, now Mr. Walker has collected it on Tanna and Lifu. Similarly, Jotus archi-pluvii, Peckh., 
was also recorded from the same place, now Mr. Walker finds it on Tanna and Mallicollo. In Mr. Hedley's collection from Fitzroy Island, Barrier, occurred Cryptothele doreyana, E. Simon, a New Guinea Spider, and the first of its genus to be recorded in Australia Another first record also is that of the nest of Brachythele pallida, L. Koch., from Canterbury, presented by Mr. H. J. Carter, M.A.

At the beginning of the year, Mr. Rainbow contributed the first of a series of articles on the architecture, etc., of Australian Spiders, chiefly based on specimens in the Museum. Part $1^{7}$ treats of the Territelariæ, or "Trap-door Spiders." This was followed about the middle of the year by Part 2-the Cribellatæ, ${ }^{8}$ or Spiders provided with a cribellum and calamistrum.

The specimens obtained by presentation numbered seventeen hundred and forty-five; by exchange three hundred and eightyone; by purchase fifty-eight; and by collection one hundred and ninety.

\section{Conchologr.}

\section{(Mr. C. Hedley, Assistant-in-Charge).}

Mr. Hedley reports:- "The past year was the most prosperous in the history of this Section. The gain to the collection exceeded the growth of two ordinary years, and more administrative work than usual was performed. This advance is due to two circumstances-(1) To the efficient aid rendered me by a Volunteer Assistant, Mr. H. L. Kesteven, who for nine months attended daily, and both sorted and roughly classified the store collection, sorted dredged material for study, rearranged all the mounted cabinet specimens, registered and mounted new material, prepared a collection for school purposes, and under your supervision attended to inquirers during my absence in July and August; (2) I profited by a special leave of absence during the months just mentioned, to visit the north-east coast of Queensland, the Barrier Reef, and intervening islands, between Townsville and Cairns. By dredging and shore collecting eight hundred and seventy-eight species of Mollusca were obtained, including a large number of undescribed or little-known forms. This collection was determined and registered, and is now in course of being mounted."

"The first quarter of the year was spent in continuing the classification of the store collection, as described in last year's Report. This disposed of, I turned to the examination of the Mollusca dredged by the 'Thetis' Expedition, which pressure of other work had delayed for three years."

7 Rainbow-Notes on the Architecture, Nesting-habits, and Lifehistories of Australian Araneidæ, based on Specimens in the Australian Museum : Part 1.-Rec. Aust. Mus., Iv., 1, 1901, pp. 5-12.

8 Rainbow-Ibid., loc. cit., 3, pp. $135-142$. 
"A thousand tablets were mounted during the year, and the contents of the old exhibition balustrade cases transferred to the new ones provided for the purpose."

A most laudable effort was made by Mr. Hedley to place on a firmer basis a number of Australian shells, described in the past by a few authors in a more or less haphazard manner. A paper of this description is his "New or Unfigured Australian Shells," in which he figured five old species described without illustrations; a second, "Revision of the Types of the Marine Shells of the 'Chevert' Expedition," ${ }^{10}$ from tropical Queensland coasts, and now in the Macleay Museum. Thirty of these "neglected species" were figured, and placed on a satisfactory basis. A third paper, "Studies in Australian Mollusca," rescued seven old unfigured forms from oblivion; and a fourth and last paper, ${ }^{12}$ Part 4 of the preceding, accounts for four other shells previously little understood, and concludes with some pertinent remarks on the 'Challenger' Australian Station, known as "164 B," from which a number of North Atlantic shells are said to have been obtained during the voyage of the vessel in question. Mr. Hedley's supposition that this should read " 64 B," a Mid-Atlantic Station, corroborated as it is by other facts, is so obvious that one wonders it has remained so long unsolved.

One of our most steadfast voluntary collectors, Mr. A. U. Henn, assisted by his brother, the Rev. P. U. Henn, both of Geraldton, W.A., surpassed his previous efforts by forwarding no less than ten hundred and sixty-eight specimens from that neighbourhood, thus providing us with a good collection of W.A. temperate Mollusca. These shells are of especial value by affording Mr. Hedley a knowledge of some of the forms originally described by Mr. C. J. Menke in his little-known work "Molluscorum Novæ-Hollandiæ Specimen," 1840, and except through this otherwise lost to history.

Mr. T. Nishikawa presented four Meleagrina martensii, Dunker, from the Bay of Agu, Japan; Mrs. G. J. Waterhouse, a constant donor, added to our collection a fine specimen of Pandopcea australis, Sby., with the siphons fully extended; and Mr. A. G. Waterhouse presented the type of Cantharus waterhousice, described some years ago by Mr. J. Brazier, ${ }^{13}$ from Botany.

There was no more liberal donor during the year than $\mathrm{Mr}$. Hedley himself. He presented to the Trustees 1,798 specimens from Japan, this continent, and various islands in the Pacific, with the conchological results of his Barrier Reef trip, consisting

9 Hedley-Rec. Aust. Mus., Iv., 1, 1901, p. 22.

10 Hedley-Loc. cit., 3, p. 121, pls. xvi. and xvii.

11 Hedley-Proc. Linn. Soc. N. S. Wales, xxv., 4, 1901, p. 721, pl. xlviii.

12 Hedley-Loc. cit., xxv., 1, 1901, p. 16, pl. ii.

13 Brazier-Loc. cit., xxi., 3, 1896, p. 345. 
of no less than 6,462 specimens, and comprising, as before stated, 878 species.

In the cases of the Invertebrate Gallery devoted to Conchology, there are now 30,681 specimens of Australasian shells, comprising 4,744 species, a large proportion being those of the celebrated "Hargraves" Collection. Elsewhere there are arranged 8,019 (850 species) specimens of foreign shells, many of which also formed a part of the same collection.

By donation, nine thousand nine hundred and sixty-six specimens were received in this section; sixty-one by exchange; and six by purchase.

Invertbbrata (other than Insecta, etc., and Mollusca).

(Mr. T. Whitelegge, Assistant-in-Charge).

"During the past year," says Mr. Whitelegge, "I was chiefly occupied with the elaboration of the Sponges forwarded by the Fishery Commissioners of N. S. Wales and Prof. A. Dendy, D.sc. In addition to preparing the published papers on these, many sections were mounted in Canada balsam for future reference."

In addition to the ordinary duties of his Section, Mr. Whitelegge rendered me valuable assistance in working out various obscure fossil forms in connection with my own special line of research.

Of Prof. Dendy's presentation, Mr. Whitelegge says:- "It consists of four hundred and seventy-eight specimens, representing four hundred and sixty-two species, and contains five species enumerated in the 'Catalogue of Sponges in the Australian Museum,' two of which, there described as new, have up to now been wanting in our collection! Of the two hundred and ninetyfive species and varieties described in this 'Catalogue,' one hundred and fifty-six are represented, including eight labelled as portions of types, and many others which are undoubtedly portions of types, now on exhibition in our Gallery. In the 'Zoologische Jahrbuch' for 1887, Dr. R. von Lendenfeld described one hundred and eighty-three species, or varieties, from Australian waters, and of the latter there are in Prof. Dendy's consignment one hundred and forty-four fragments, many of them probably bits of the original types now in the Museum of Natural History, London, notwithstanding that a large proportion of the species are labelled Port Jackson, or from the coast of N. S. Wales."

In my Report for 1900, I referred to the collection of Sponges received from the Fishery Commissioners, and Mr. Whitelegge's important work in connection therewith. His researches were completed early in 1901, and the results published. ${ }^{14}$ The collection

13 Whitelegge-Report on Sponges from the Coastal Beaches of New South Wales.-Rec. Aust. Mus., iv., 2, 1901, pp. 55-118, pls. x. - xv. 
of over six hundred specimens yielded seventy-one species, ten of which were described as new. The commercial class of sponge is represented by twelve species and varieties, seven or eight of which may be regarded as having an economic value and belong to the genera Euspongia and Hippospongia. The most important economically is Hippospongia illawarra, Whitl., "being quite equal, if not superior, to many of the kinds used for domestic purposes." The work necessitated the preparation of two hundred and fifty microscopic sections, as well as the macroscopic and microscopic re-examination of one hundred and twenty specimens already in the Museum.

The investigation of these sponges again brought under $\mathrm{Mr}$. Whitelegge's notice the chaotic condition of the Lendenfeldian types, a most regretable state of things when we remember that this collection is supposed to be one of the chief, if not the chief authority, for Australian Sponge nomenclature. A summary of the results arrived at by Mr. Whitelegge during his examination of Lendenfeld's types deposited in this Museum, is as follows:Eighty-nine species and varieties were examined, and forty-three (nearly half !) were found to be wrongly or insufficiently diagnosed, or deducting the Horny Sponges, which are much less likely to error in the diagnosis of the fibres, the numbers are thus :-

\begin{tabular}{|c|c|c|}
\hline & $\begin{array}{l}\text { Species and } \\
\text { Varieties } \\
\text { examined. }\end{array}$ & $\begin{array}{l}\text { Wrongly or } \\
\text { insufficiently } \\
\text { diagnosed. }\end{array}$ \\
\hline \multirow{4}{*}{ 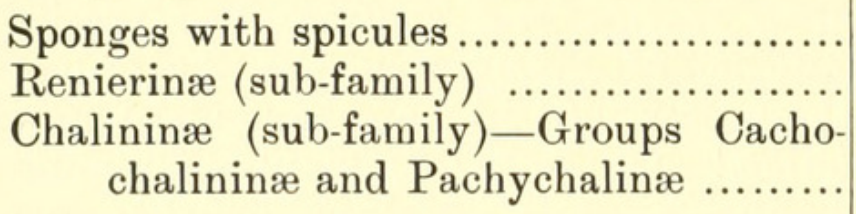 } & 28 & 14 \\
\hline & 10 & 7 \\
\hline & & \\
\hline & 20 & 13 \\
\hline \multirow{3}{*}{ Add Horny Sponges } & 58 & 34 \\
\hline & 31 & 9 \\
\hline & 89 & 43 \\
\hline
\end{tabular}

An example of one of the most beautiful of known Sponges, Venus' Flower Basket (Euplectella aspergillum, Owen), from the Philippines, was presented by Mr. W. Cruickshank; and two specimens in alcohol of the second species, $E$. imperialis, Ijima, from the Bay of Agu, Japan, were given by Mr. Tokichi Nishikawa, of the Imperial Fishery Bureau, Tokio; with six examples of the Glass-rope Sponges (Hyalonema apertum, Schulze, and $H$. sieboldii, Gray), from Japan also, by Mr. S. Koaze.

It is of some importance to note that a commercial sponge exists at Manahiki, or Humphrey Island, Euspongia irregularis, var. pertusa, examples having been presented by the Directors of the Pacific Islands Company, of this city. Amongst the specimens 
obtained by Mr. Hedley at Palm and Gould Islands, Barrier Reef, was a species of Gellius, commensal with an alga.

By exchange with the West Australian Museum, Perth, twentyfour specimens were obtained, half of which were new to our collection.

There are now exposed to public view three hundred mounted specimens of Australian Sponges.

A remarkably fine series of Corals, numbering fifty-nine specimens and thirty-three species, was brought from Palm Island, Barrier Reef, by Mr. Hedley, with equally good examples of Heliopora coerulea, Pal., one with extended polyps, and an example of the Giant Anemone (Discosoma kentii, Had.). Our exhibition cases now contain three hundred specimens of Australian Corals.

Two rare Land Crabs (Geocarcinus lagostoma, M. Edw., and Discoplax longipes, M. Edw.), were brought from Ocean or Pleasant Island, by Messrs. F. Danvers Power and A. E. Stephen. From Lord Howe Island, we received a Crab (Lumbrus affinis, M. Edw.), obtained by Mr. W. S. Thompson, previously known only from Torres Straits, New Caledonia, and the Hawaiian Islands. Another interesting addition to the fauna of this beautiful Island, was a new Hermit Crab (Calcinus imperialis, Whitl.), ${ }^{14}$ inhabiting the shells of Turbo imperialis, Gmelin. The presence of the much-dreaded Gribble (Limnoria lignorum, Rathke), in wood taken from one of the jetties at Circular Quay, and from a ferry steamer, was shown by Mr. Whitelegge ${ }^{15}$ to be an accomplished fact.

A further valuable collection of Planarians, including thirty-one specimens, representing fifteen species and varieties, seven of which are types, was presented by Mr. Thomas Steel.

During 1901, thirteen hundred and sixty-two specimens were received by donation; thirty-four by exchange; twenty-four by purchase; and seventy-four were collected.

\section{EThNOLOGY.}

(The Curator; Mr. W. W. Thorpe, Mechanical Assistant).

The collection of Australian and Polynesian Ethnology continues to increase, and the acquisitions were both interesting and valuable.

Dr. W. E. Roth continued to supply us with examples of Mollusca, used by the North Queensland Aborigines as food, thus adding fifty-five varieties to the excellent series already supplied by the same gentleman. A complete list of the edible Mollusca

14 Whitelegge-Description of a New Hermit Crab (Calcinus imperialis), from Lord Howe Island.-Rec. Aust. Mus., iv., 1, 1901, pp. $48-51$, pl. ix.

15 Whitelegge-Limnoria lignorum, Rathke-a Wood-borer : its recurrence in Port Jackson.-Loc. cit., 3, p. 143. 
of North Queensland, as used by the Blacks, has lately appeared from the pen of Dr. Roth,${ }^{16}$ the species having chiefly been named for him here by Mr. Charles Hedley.

Four excellent "Nardoo" stones were contributed by Mr. J. S. Jackson, from Flood's Creek, seventy miles from Broken Hill, and another by Inspector W. Webster, of the Lands Department.

The Directors of the Pacific Islands Company, of Sydney, were good enough to donate a number of most acceptable Ethnological articles, procured for them by Messrs. F. Danvers Power and A. E. Stephen, from Ocean and Pleasant Islands. With these was a large lagoon fishing-net, contributed by Mr. A. Ellis, of Ocean Island; and a very handsome dancing petticoat, or kilt, from Niutao, Ellice Group, was presented by Mr. J. G. Whibley.

Two curious Gold Prospecting-dishes from Soepajang, Sumatra, were presented by Mr. E. V. Bensusan; a series of specimens illustrating the manufacture of the shell money known in New Ireland as kokonon, was presented by Mrs. E. E. Kolbe, of Ralum, New Britain; another very interesting corselet, from the Gilbert Group, was given by Mr. A. E. Finckh; and an additional ancestral drum, from Mallicollo, by the Rev. J. Paton.

Three hundred and forty-six specimens were presented; eight were obtained in exchange; and three hundred and twenty-nine by purchase.

\section{Historical.}

(The Curator; Mr. W. W. Thorpe, Mechanical Assistant).

The Museum is indebted to the State Premier(Hon. J. See, M.L.A.) for a valuable present, consisting of a finely-carved black-wood cheval-glass, two large silk umbrellas, and a standard, "loot" obtained in Pekin, and brought on their return by the N. S. Wales Naval Contingent.

From Major-General Pretyman, Bloomfontein, we received eight Boer rifles, used in the present South African campaign, including Martini-Henry, Westley - Richards, Westley - Richards Sporting, D.B. Sporting, and a Mauser rifle.

By donation twenty-seven specimens were acquired during the past year.

\section{Numismatics (Coins, Tokens, Medals).}

(The Curator; Mr. W. W. Thorpe, Mechanical Assistant).

The general collection of coins and foreign tokens had, up to the commencement of last year, never been examined in anything approaching a critical manner. A commencement was made in

16 Roth-Food: Its Search, Capture, and Preparation.-N. Queensland Ethnol. Bull., No. 3 (Queensland Parl. Papers, C.A. 81, 1901). 
January by sorting the coins proper into countries and reigns, with preliminary determinations, and subsequent rough arrangement in a large cabinet, specially made for the purpose on the premises. Having accomplished this with the aid of my personal assistant, Mr. W. W. Thorpe, who has shown special aptitude for the work, the tokens, other than the Australian, were sorted, determined, and systematically arranged for reference by students. No attempt has yet been made to classify the Greek and Roman. To my astonishment I found that the Trustees possessed a most valuable series of Chinese coins, consisting of one thousand and ten pieces. From the catalogue accompanying them, the coins purport to have formed the collection of one Hwong Ping Sing, of Fuchow, gathered by himself during twenty years' collecting, and arranged in accordance with Chinese and Japanese 'Chronicles of Coins.' All in the catalogue agree fairly well with the descriptions given by Lockhart in his work, 'Currency of the East. ${ }^{17}$

The catalogue is divided into six sections, viz. :-

(1) Coins of the Ancient Dynasties, circa 770 B.C. to 1616 A.D.

(2) Coins of the present Manchurian Dynasty, from 1616 to 1862 (including Rebel coinage).

(3) Annamese Coins (Cochin China), 1010 to 1427 A.D.

(4) Japanese Coins, 708 to 1864 A.D.

(5) Corean Coins (no date given in Lockhart).

(6) Coins used as Amulets.

Paper money was increased by the presentation of a five and a ten Chinese tael note, by Mr. F W. Luscombe.

The collection of Medals was largely added to during the year. Under the head of Commemorative Medals, we received a copy of the fine bronze medal struck by the Corporation of the City of London, to commemorate the "Raising and Equipment of the City Imperial Volunteers, and their Service in South Africa in 1899 - 1900," by F. G. Frampton, A.R.A.

To the kindness and ability of Mr. Emil Fuchs, of London, we are indebted for two medals, designed and executed by him. One is "To the Memory of those who gave their Lives for Queen and Country," and relates to the present Boer war. The second was a commission to Mr. Fuchs from the Queen, and was intended by the latter as a personal memorial of the end of the century. It is executed in dull oxidised silver. The profile head of Her Majesty on the obverse is said to be one of the best likenesses that any sculptor or medallist has yet achieved.

A number of medals or medaletes, commemorative of Australian Federation were struck locally, five officially, the remainder as private commercial speculations. Examples of all, in duplicate, were secured for our collection.

17 Lockhart-'Currency of the the East,"' i. and ii., Hongkong, 1895. 
In this section sixty-six specimens were presented; sixteen acquired by exchange; and fifty-seven by purchase.

\section{Mineralogy.}

(Mr. T. Cooksey, Ph.D., B.Sc., Consulting Mineralogist;

Mr. C. Anderson, M.A., B.Sc., Assistant-in-Charge).

As Dr. Cooksey, in his temporary capacity, attended merely to the determination of acquisitions, principally the previously purchased Porter Collection, the general conduct of the Mineral Section fell on myself until the arrival of Mr. Anderson, i.e., from January to July. During that period my Assistant, Mr. W. W. Thorpe, registered no less than 10,143 specimens, and helped me to incorporate them in the collection. In the fore part of the year, with the assistance of $\mathrm{Mr}$. B. Lucas, the steady replacement of old MS. labels by printed ones progressed, and a number of additional specimens was placed in the cases.

On Mr. Anderson's arrival, his attention was given to the rearrangement of the case containing specimens illustrating the occurrence of gold, and cut and rough gem-stones. These were all remounted, augmented, and supplied with printed labels.

An addition to our collection was made by Mr. Herbert Basedow, by the presentation of Stibio-tantalite, from Greenbushes, W.A. Mr. S. L. Bensusan presented Stannite from Boro Creek, and Mr. D. A. Porter the same mineral from Howell. Messrs. F. Danvers Power and A. E. Stephen collected samples of the phosphatic deposits at Ocean and Pleasant Islands, and added typical examples to our series. A small general collection of Australasian minerals was presented by Mr. R. J. Etheridge.

By exchange, a copy of the Boogaldie Meteorite was obtained from the Technological Museum, Sydney; and one of the Rhine Valley Meteorite from the School of Mines and Industries of South Australia, Adelaide.

Two hundred and nineteen specimens were acquired by donation; four by exchange; and ninety-eight by purchase.

\section{Paleontology.}

(The Curator; Mr. W. W. Thorpe, Mechanical Assistant).

The principal professional work performed by myself, was the determination in the early part of the year of $(a)$ the collection of Queensland Cretaceous fossils, forwarded by Mr. W. H. Blomfield ${ }^{18}(b)$ a series of Platyschismæ for the Tasmanian Museum; (c) Cambrian Trilobites for the Government Geologist of South Australia; (d) Cretaceous fossils from South Australian locali-

18 Etheridge-Report for the Year 1900.—Rec. Aust. Mus., iv., 4, 1901, p. 173 . 
ties, for the same; (e) Silurian fossils from Tasmania, for the Government Geologist of that State; $(f)$ study of a new genus of Permo-Carboniferous Gasteropoda (Keeneia); ${ }^{19}(g)$ study of Palæozoic Corals and material prepared for publication; $(h)$ a very interesting study of cone-like Stroboli, attached to foliage resembling that of Phyllotheca, ${ }^{20}$ which adds another form of fructification to those already described as appertaining to this plant; $(k)$ study of a Mesozoic Bivalve (Ctenostreon) from Western Australia, ${ }^{21}$ which, although casually recorded once before, had neither been figured nor described; $(l)$ identification of a Lingula associated with Lepidodendron, ${ }^{22}$ marking a well defined horizon in beds believed to be of Upper Devonian age, in the Canobolas section near Orange. Finally some time was given to the study of a series of Cretaceous fossils received from the Government Geologist of Natal; I hope to prepare a report on this collection in the future, but it will take some time.

Our Permo-Carboniferous Mollusca were increased by gatherings made by Mr. W. S. Dun, at Wollongong, and presented by him; and from Tasmanian localities by Mr. T. Stephens, M.A., and Miss G. King. Another tail core of the Horned Lizard (Miolania platyceps, Owen), was received from Mr. J. B. Wilson, of Lord Howe Island, and Molluscan casts from the Phosphatic deposits of Ocean and Pleasant Islands, which appear to be those of living species, presented by Messrs. J. T. Arundel and F. Danvers Power.

An interesting fossil was presented by Mr. Thomas, proving the existence of the genus Straparolus ${ }^{23}$ in the Lower Marine Series of the Permo-Carboniferous in N. S. Wales. This has been described by me as $S$. ammonitiformis.

Some of the finest examples I ever saw of that very beautiful organism, the Chain Coral (Halysites), were presented by the Rev. J. Milne Curran from a locality near Orange; these I hope to describe at some future date.

Another interesting geological discovery was that by Mr. E. Lowe, of a very refractory and highly fossiliferous limestone, covering a large extent of country around Ravensleigh Station, Gregory River District, Carpentaria. This limestone contains bones of mammals and birds, with land and fresh-water shells of

19 Etheridge-A new Permo-Carboniferous Genus (Keeneia) of Pleurotomariidæ, etc.-Rec. Aust. Mus., iv., 5, 1902, p. 195, pls. xxxii.- xxxiii.

20 Etheridge-Cone-like Strobili, attached to a Phyllotheca-like foliage. -Loc. cit., 1, p. 1, pls. i. and ii.

21 Etheridge-Ctenostreon pectiniformis, Schlotheim, an Australian fossil. -Loc. cit., 1, p. 13, pl. xiii.

22 Etheridge-Lingula, associated with Lepidodendron.-Loc.cit., 3, p. 119.

23 Etheridge-A Straparolus in New Soutb Wales.-Rec. Aust. Mus., iv., 5, 1902, p. 200, pl. xxxiii., figs. 1 and 2. 
existing species. The chief specimen of interest, however, was a partial Crocodile skull that in its present condition is indistinguishable from that of the living coast form, $C$. porosus.

In last year's Report, I referred to some tree-trunks of Cretaceous age, bored by Teredo, as forming part of the collection presented by $\mathrm{Mr}$. H. W. Blomfield; this borer has now been described as Teredo vastitas. ${ }^{24}$

Two hundred and ninety-six specimens were presented; one hundred and four obtained by exchange; and seventy-eight purchased.

\section{LIBRARY.}

(Mr. S. Sinclair, Librarian; Mr. F. T. Clark, Assistant).

The need of more accomodation in the Library for the storage of books, or, to be strictly exact, the need of a larger Library, is beginning to be felt, as well as the want of assistance to register and catalogue, and to supervise the issue and return of books. The books and shelves were thoroughly cleaned during the year.

The acquisitions numbered five hundred and sixty-six volumes, besides pamphlets and unbound parts of periodicals.

The Trustees Exchange List of Corresponding Societies and Institutions now contains about three hundred names, from most of which valuable return exchanges are received. In fact the bulk of the acquisitions to the Library of late years has come from this source, our ability to purchase being very limited.

\section{OFFICE.}

(Mr. S. Sinclair, Secretary; Mr. F. T. Clark, Clerk).

The work of the office, inclusive of correspondence, accounts, and general business, is naturally increasing in proportion to the general work of the Museum, and further clerical assistance is much wanted. All documents and accounts were closed at the end of the year.

2t Etheridge-Two Undescribed Pelecypoda from the Lower Cretaceous of Queensland, etc.-Loc. cit., p. 201, pls. xxxiv., $x \times x v$. 


\section{$2 \mathrm{BHL}$ Biodiversity Heritage Library}

Etheridge, Robert. 1902. "Report for the year 1901." Records of the Australian Museum 4, 217-252. https://doi.org/10.3853/j.0067-1975.4.1902.1100.

View This Item Online: https://www.biodiversitylibrary.org/item/31165

DOI: https://doi.org/10.3853/j.0067-1975.4.1902.1100

Permalink: https://www.biodiversitylibrary.org/partpdf/3521

\section{Holding Institution}

Harvard University, Museum of Comparative Zoology, Ernst Mayr Library

\section{Sponsored by}

Harvard University, Museum of Comparative Zoology, Ernst Mayr Library

\section{Copyright \& Reuse}

Copyright Status: NOT_IN_COPYRIGHT

This document was created from content at the Biodiversity Heritage Library, the world's largest open access digital library for biodiversity literature and archives. Visit BHL at https://www.biodiversitylibrary.org. 